\title{
THE SONG OF NIBELUNGEN BODIES AND HOW THEY ARE DESCRIBED, IDEALISED AND EROTICIZED. PART I. DER HELT WAS WOL GEWAHSEN...
}

\section{Elina A. Sarakaeva (a)}

(a) Hainan State University. Haikou, China. Email: 2689655 292[at]qq.com

\begin{abstract}
The discovery of the medieval heroic epic "Das Nibelungenlied"in the XIX century Germany coincided with the search for new national mythology and symbols within the movement of Romantic medievalism. The heroic epic got a country-wide recognition asa great literary work that was supposed to serve as a source of German values and to reflect the German national character. With this approach the characters of the epic were re-constructed as embodiments of these German values, as ideals to follow. The article analyses the iconography of these characters, the "nibelungs": the way they were visualized and depicted in fine arts and fiction and what ideological concepts were ascribed to their bodies and appearances. The first part of the article compares the descriptions of Nibelungen characters in the works of German authors of XIX-XXI centuries and compares them to the descriptions in the original text of the poem to see how cultural codes are constructed and interpreted through visualization of human bodies.
\end{abstract}

\section{Keywords}

the nibelungenlied; heroic epic; nibelungs; description; body; appearance; medieval literature; imagery

\section{(c) (i)}

This work is licensed under a $\underline{\text { Creative Commons «Attribution» } 4.0 \text { International }}$ License. 


\title{
ПЕСНЬ О ТЕЛАХ НИБЕЛУНГОВ И О ТОМ, КАК ИХ ОПИСЫВАЮТ, ИДЕАЛИЗИРУЮТ И ЭРОТИЗИРУЮТ. ЧАСТЬ І. ХОРОШ СОБОЙ БЫЛ ВИТЯЗЬ...
}

Саракаева Элина Алиевна (а)

(a) Хайнаньский профессиональный колледж экономики и бизнеса Хайкоу. Хайкоу, Китай. Email: 2689655 292[at]qq.com

\begin{abstract}
Аннотация
Открытие средневекового героического эпоса «Песнь о нибелунгах» в Германии XIX века совпало с поиском новой национальной мифологии и символики в движении романтического медивиализма. Героический эпос получил признание в масштабах всей страны как великое литературное произведение, которое должно было служить источником немецких ценностей и отражать немецкий национальный характер. При таком подходе персонажи эпоса были осмыслены как воплощения этих немецких ценностей, как идеалы для подражания. В статье анализируется иконография этих персонажей, «нибелунгов»: то, как их изображали и интерпретировали в изящных искусствах и художественной литературе, и какие идеологические концепции прочитывались в их телах и внешности. Первая часть статьи сравнивает описания персонажей "Песни" в произведениях немецких авторов XIX-XXI веков и сравнивает их с описаниями в оригинальном тексте поэмы, чтобы увидеть, как культурные коды строятся и интерпретируются посредством визуализации человеческих тел.
\end{abstract}

\section{Ключевые слова}

“Песнь о нибелунгах"; героический эпос; нибелунги; описание; тело; внешность; средневековая литература; образный ряд

\section{(c) (1)}

Это произведение доступно по лицензии Creative Commons «Attribution» («Атрибуция») 4.0 Всемирная 




The heroic epic "Das Nibelungenlied" ("The Lay of the Nibelungs"), written presumably at the beginning of the XII century in the Middle High German language, became a landmark literary work in XIX century Germany, during the period of liberation wars against Napoleon's troops. Interest in the poem grew out of the literary and philosophical movement of romanticism and contributed to the awakening of national selfconsciousness during foreign occupation.

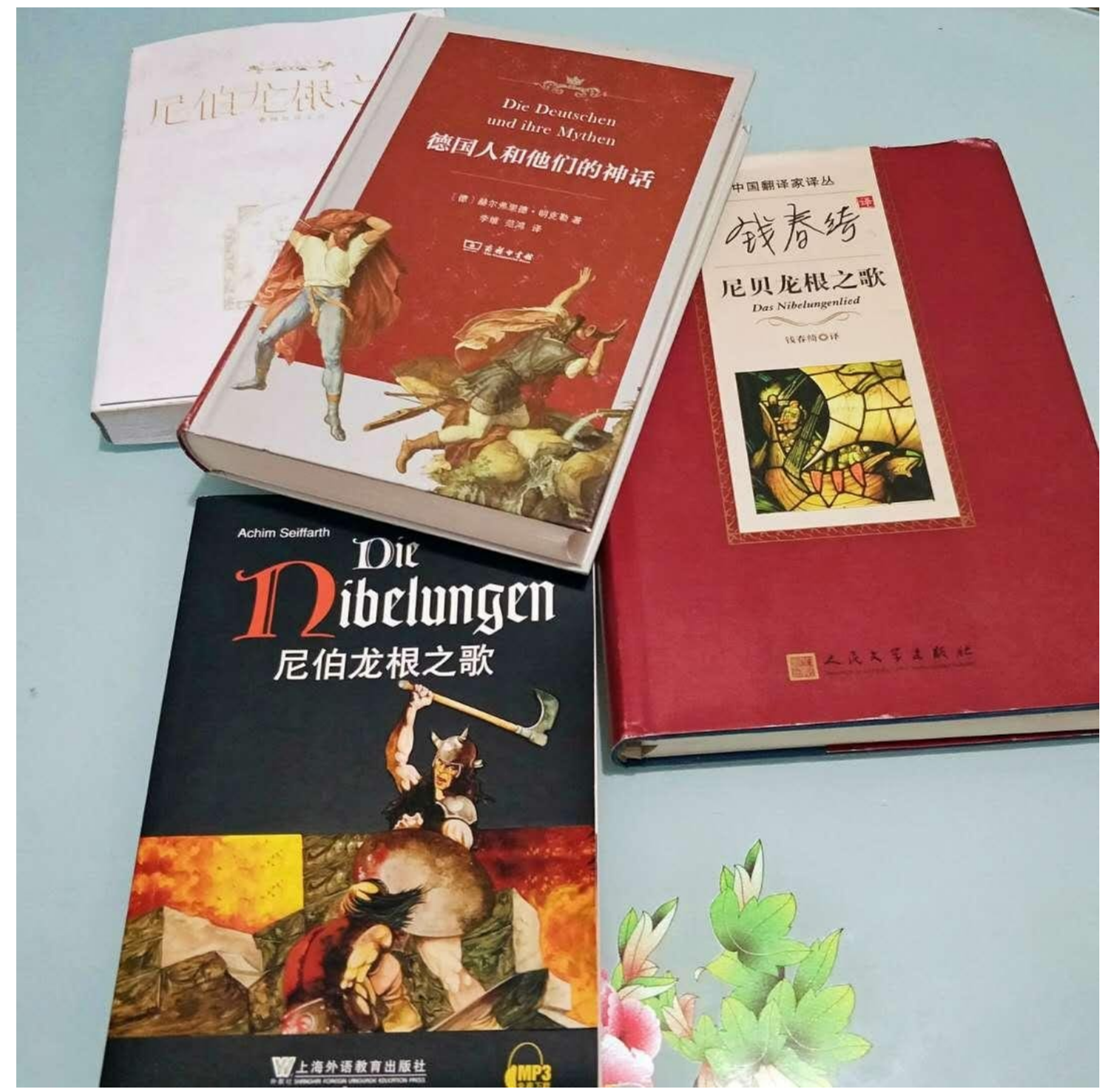

Fig. 1. Translations of the "Nibelungenlied" into the Chinese language.

Romantic medievalism was the trend of the period. Brothers August and Friedrich Schlegel, Friedrich Schelling, Georg Hagel, Friedrich Hölderin and other philosophers and men of letters expressed a desire for a new mythology, rooted in ancient times, a mythology that would not 
copy or reflect classical Greek and Roman antiquity, but would be genuine and German. The discovery or rather re-discovery of the medieval heroic epic "Das Nibelungenlied" seemed an answer to this cry. The epic was recognized to be "a wonder of nature", "a grand work of art" comparable to Greek "Iliad"; the Schlegel brothers expected it to become "the foundation of our poetry" (Ehrismann 2002, p. 220). The epic was published and republished, sometimes mixed with Nordic sagas in an attempt to reconstruct the true German antiquity. Within the movement of Romantic medievalism 'The Nibelungenlied" was considered a collected creation that reflected the German national character.

In the course of the XIX century the Lied was loaded with a task of teaching and popularizing true German values ("Nibelungen values") and be a foundation of a new German glory. The importance of the Lied was emphasized by philologists, philosophers and educators (Sarakaeva 2019), it made its way into public tribunes and school curriculum. Otto Ehrismann points out that the epic "provided the German-speaking lands with powerful stereotypes" that would be used through World Wars First and Second (Ehrismann 2002, p. 221).

To these stereotypes clearly belonged the image of Siegfried the dragon slayer, the image of Hagen who is simultaneously a treacherous killer and a vassal of unbending loyalty, the concept of Nibelungentreu (the loyalty of Nibelungs) with its image of determined and death-defying warriors, the concept of invincibility, the dream of mystical Nibelungen treasure, the worshiping of youth in all its positive aspects like strength and beauty, the imagery of blond-haired German heroes and heroines, the opposed images of barbarian shield-maidens and lowly people of inferior races, the understanding of the quarrel between the fair German heroine Kriemhild and wild Brunhild as an ever-lasting struggle between Culture/ Civilization and Nature etc.

The visual representation of these new notions and images manifested itself in the works of German writers inspired by the epic. Such literary adaptations were abundant in the course of XIX - the beginning of XX centuries and almost every writer used descriptions of their characters' bodies and facial features as an artistic means of character representation, as a way to show what kind of people they were, who was good and who was bad.

To present Siegfried as an embodiment of true German masculinity this kind of task was consciously undertaken by the great composer Richard Wagner, who not only created his Siegfried as a masculine ideal for audience but also theorized upon it in his essays. Wagner, in his "endless quest for manhood" (Köstenbaum 1993, p. 205) called for 


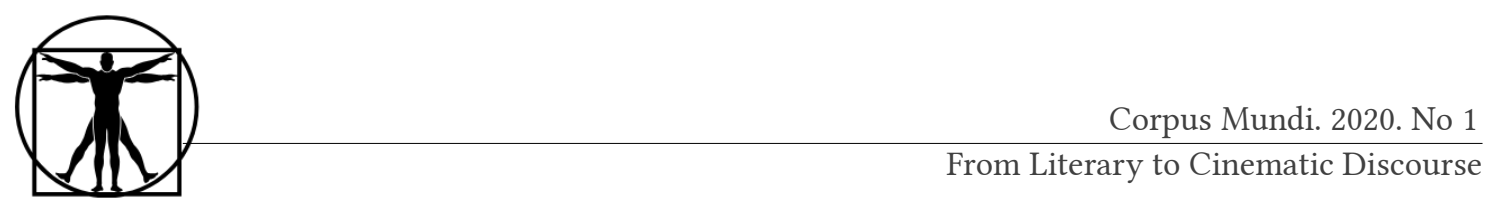

Germans to realize their own creative capacity, and the image of superhero Siegfried that he created in his Ring-operas was setting the example for contemporaries to follow. Siegfried was to be an icon of "the most chaste beauty", of perfect masculinity, the one desired by females and followed by males. "For me he was the embodied masculine spirit of the eternal and the solely productive instinct, the doer of true deeds" wrote the composer in his essay "A Message to my Friends" (Wagner 1983, 290).

Generalized images of all major characters of Nibelungen legend can be found in the prose rendering of the "Lied" by Rudolf Herzog, a XIX century secondary German writer. His visualization is so characteristically standard and typical for the whole generation of Nibelungen authors that I find it worthwhile to comment on some of his descriptions. For though Herzog was certainly no match for the best of "Nibelungen" authors Friedrich Hebbel and Paul Ernst, he definitely epitomized the popular imagery in his work "Die Nibelungen". We see Siegfried, a young man as handsome as spring, inspiring love and admiration in all who see him, in a truly Wagnerian sense:

"Golden hair flew around his head as if he had caught the sun in his curls. Steel blue were his eyes and so happy and soft was their shine, so glowingly and flashingly they could sparkle and blaze. His body was so well-built that it delighted women to look at him, his arms were iron and his thighs of untiring strength on the horseback" (Herzog, 1912, p. $17)^{1}$

This rather bombastic description has a usual set of a "German hero": blue glowing eyes, flowing golden hair, a muscular body etc. The author pays heed to the female gaze that follows Siegfried with desire. Another good male character can also boast blonde hair and shining blue eyes: "Gieselher was almost yet a child, with blond locks and blue rapturous eyes" (ibid. 39). The good heroine will naturally have these three essential features too - blue shining eyes, long golden hair and fair body. The author describes Kriemhild to be

"slim and fair, with blue shiny eyes. And when she lets her blond hair run loose, it falls like a mantel of light sunny waves down to her slim feet covering completely her beautiful body" (p. 46)

1 Translation from German is mine, E. Sarakaeva 
Now come the baddies and their faces naturally betray the flaws of their characters. Thus, Gunther "was tall and well-built, but a haughty arrogance lay on his features, and lust for power was in his eyes" (p. 39). Hagen is "a lean and bony man with a dark black-bearded face. He had one one eye that glistened sharply from under his bushy brows" (p. 40). Bad characters, especially Hagen, are in a habit of shining, sparkling and glowing with their eyes too, but they do it in a scary sinister way accompanied by their scary sinister laughter.

All of this makes the reader's task of moral evaluation of the conflict pretty easy. The one with the dark hair is bad and is soon going to do something terrible, while the the yellow-haired person is good and will soon be made to suffer. Yet with all the banality of such symbolism the author seems to be genuinely enraptured in his imagery. He needs to see it all - their faces, their bodies and their clothes and returns to their appearances again and again. This is how he draws the scene of the queens' quarrel:

"Gunther's wife was clad in purple silks that matched so well her black hair. Siegfried's blond wife looked like bright morning in her light-blue gown" (p. 89)

But even uglier than demonic Hagen is Herzog's Etzel, king of Hunns. He is

"a short, lean man with a yellow face, his body wrapped in an inconspicuous buffalo skin". His face is a "disgusting face of a Hun", that "can't be compared with Siegfried's spring-like beauty" (p. 26).

He says so himself:

"I am small of height and disgusting, while the hero who was your previous husband was more magnificent than any other man"(p. 127).

Here we have the typical representation of an unfriendly Stranger with one of its basic features - strange and ugly appearance and clothes, which, as S. Yakushenkov and O.Yakushenkova show, constitute the Triad of the Stranger, together with wild and unruly sexual life and strange gastronomy tastes (Yakushenkov \& Yakushenkova, 2010). The other two parts of the Triad can also be found in the text. In the chapter where the King of Huns treat the Burgundian guests to a great feast the author enumerates different delicacies that were put on the table, but then, as if 


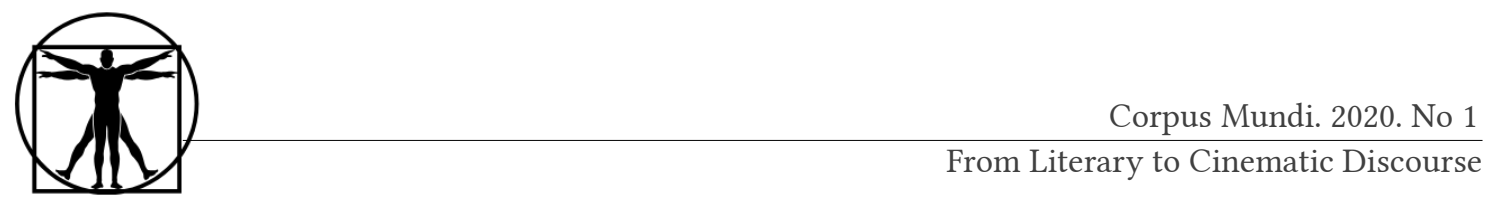

suddenly realizing that these dishes - meat, fish, poultry - are too usual to be served in the land of the wild Huns, he adds that the Hunish warriors "ate at the separate table and according to their own tradition" (p. 236). In the above extract where King Etzel first meets Kriemhild, he is dressed for some reason "in an inconspicuous buffalo skin", though just a few sentences above we learn that "never has Kriemhild seen such riches in her life", which corresponds to the actual phrase in the ancient heroic epic. Yet, King Etzel, the owner of these riches, is dressed poorly in an animal skin just because he is a barbarian, a Stranger. And being a lowly barbarian Stranger, he cant believe that a beautiful woman of the superior race has agreed to become his wife, him being the conqueror of the world, the master of great treasures and all (Fritz Lang stresses the same attitude in his famous film "Die NIbelungen. Kriemhild's Revenge": the ugly ruler of the barbarian tribe is amazed that a proud German maiden agreed to marry him and prostrates himself at her feet). His "disgusting yellow face of a Hun" and short height are underlined again and again contrasting with the main hero's and heroine's true Aryan beauty.

Wagnerian ideas "of coding the body with political and cultural meanings" (Pursell, 2008) manifest themselves in many literary works of the time, including dramatic adaptations of "The Nibelungenlied" that were staged in German theaters one after another.

EmanuelGeibel in his play "Brunhild" uses very few descriptions of countenance and for that employs trite and predictable adjectives. We learn of Iceland maidens that they are "blonde and fair" or "white-armed and fair" (Geibel 1879, p. 7), a youngster has "rosy lips" (p. 39), a male warrior is of "manly beauty" (p. 36). More interesting is the appearancerelated reason that the title heroine gives to explain why she trusts Hagen:

"Bleib, Hagen! Du bist treu; du trägst ja

Kein wallend Goldgelock und wußtest nie

Von süßer Rede” (Geibel ,1915, p. 68).

"Stay, Hagen! Thou art true, thou wearest

No flowing golden locks, nor e 'er hast known

Of sweet discourse" (Geibel, 1879, p. 80).

Basically the heroine says that Hagen is trustworthy because he is not handsome with a traditional golden-hair type beauty (the way Siegfried is) and thus must be a man of his word. The heroine in her despair generalizes bodily characteristics of the man who has betrayed 
her - Siegfried, and ascribes opposite character features to a person who doesn't look like Siegfried. It's worth noting that nowhere in the play the author describes Siegfried's appearance; the fact that he has "flowing golden locks" is supposed to be a known fact to all the readers/viewers.

The real hit of the time was the trilogy "Die Nibelungen" by the prominent German playwright Friedrich Hebbel. His plays with all their faults and merits are still considered to be the best dramatization of the heroic epic. Hebbel's reading of the Lied is not very politicized, he tries psychological approach to the treatment of the characters, while his attempts to deepen the meaning of the plot by depicting conflicts between Christianity and Paganism remain surface-layered and artificial. Avoiding Herzog's blatant and childish descriptions of appearance Hebbel tried to build these descriptions into the plot. He, too, feels the need to characterize his heroes by their looks, but does it in a subtler way. When Brunhild first sets foot on Burgundy's soil it suddenly turns out that she is somehow colour-blind. Her homeland is more of the Otherland than real geographical Iceland, and there were no colors in this strange place. Brunhild can distinguish only red, blue, white and black colors, not because she saw them in the nature but solely because her different body parts have these colors:

"We know not blue unless we see blue eyes

And those we only have with ruddy hair

And milk-white faces!" (Hebbel, 1914, p. 213)

“.....yet my hands

Have taught me white and raven is my hair" (p. 214)

Hebbel, too, juxtaposes the beauty of haughty black-haired Brunhild and the traditional feminine fairness of Krumhild and through Siegfried's lips rejects the former in favour of the latter:

"That thou art living, smiling

I give thee thanks; and that thine eyes are blue.

I love not black" (p. 248)

Yet Kriemhild seems to be not so excited about what later would be called "objectifying of women". When Siegfried says that he loves her and is thankful to her for her beauty she mildly reproaches him: 


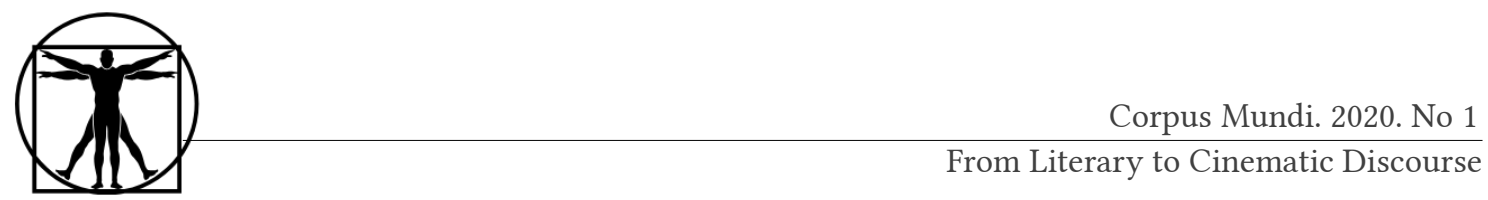

“Thou only see'st God's and nature's gifts

In all that's mine, but my own handiwork

The raiment that adorns me, thou see'st not

Not even the fair girdle that I wear" (p. 248)

Here she insists that her husband ought to pay more attention to the clothes she wears than to her good looks. Strange opposition, a modern reader might think, but Kriemhild means that by adorning herself with jewels and beautiful clothes she willingly tries to please her husband's eye, while her bodily parts do not depend on her own will and can't be regarded as a token of her love for Siegfried. Then she generalizes that male warriors do not pay attention to clothes and includes Hagen (who is a father-figure for her at that stage of plot development) into the list:

"See thou just like my uncle Hagen

Who if one lays a garment by his bed

That one has made in secret will not heed

Unless perchance it is too tight" (pp. 247-248)

The question of garments will be mentioned in the last part of the trilogy again, when Burgundians see King Etzel wearing the clothes of the enemy he has slain. This makes Hagen burst into sardonic laughter and he remarks that on the scale of villains he himself must not be listed too low - he, at least, doesn't wear dead Siegfried's rags.

In the years preceding the outbreak of the First World War, the praises to the heroic epic are sung in friendly chorus: "Nibelungenlied" is to be looked upon as the quintessence of the German spirit and the textbook of German values, namely: loyalty, desire for fame, honor, strength, courage, and - most importantly - contempt for death. Siegfried, this Nietzschean "blonde beast", has become universally acknowledged highest model of a Germanic hero.

During the Weimar Republic interpretations continue to evolve in the same spirit. The Lied becomes the song of the German nation, becomes a thread, linking together German national identity disintegrating under the pressure of internal and external disasters. German authors appeal to Siegfried to defend the country and breathe in the heroic spirit into his descendants:

Held mit den blonden Haaren /Und mit dem schweren Schwert!

(Oh, hero with blond hair / And with the heavy sword)

- cries out poet Josef Weinheber (Weinheber, 1972, p. 311) 
Other poets, like Börries von Münchhausen, appeal to Siegfried's murderer Hagen: he embodies resistance to the blows of fate, unbending loyalty and the willingness to meet death face to face (Münchhausen, 1959). The outstanding German author Bertoldt Breht makes fun simultaneously of these appeals to imaginary archetypes of German heroes and their presumed Nordic appearance in his poem "Siegfred had red hair":

Siegfried hatte ein rotes Haar / Und Hagen Tronje liebte ihn sehr; (Siegfried had red hair / And Hagen Tronje was very much in love with him) (Brecht, 1993, p. 492)

Here both the appearances of Nibelungen heroes and their relations are twisted: Siegfried is red haired not blond, Hagen is in love with him and kills him out of homosexual desire.

After the defeat in the Second World War the favourite Nibelungen heroes undergo de-sacralization, the "Nibelungenlied" is subjected to harsh and single-sided criticism. It is stigmatized as apology of German militarism, it is criticized for what was previously praised. The characters on the stage of German theaters are portrayed as odious militarists obsessed with the spirit of murder and self-destruction - such are the plays by Moritz Rinke, Heiner Müller and many others. A critical rethinking of the plot and its cultural function often translates into burlesque: different authors expose the plot to ridicule, many of them create satirical works of dubious artistic merit based on the poem (E.g. Rideamus, 1989)

It's interesting that modern adaptation of the heroic epic employs the description of characters' appearance and especially clothes too, but with different artistic function. Now this sort of description is used for belittling the characters, for exposing their vanity and pettiness. The trilogy "Nibelungs" of modern German playwright Moritz Rinke gives a good example:

"Groom: Noble lady, I have five hundred warriors with me, all seasoned in battle, and all of them are dressed in the best Bavarian velvet, and they have brought here gifts of jewelry to you! There they stand at the gate!

Ute: What, everyone is wearing Bavarian velvet?

Kriemhild: Thank you, quite enough! And why, pray tell me, are these five hundred people wearing Bavarian velvet? 
Ute: You are too fast in your judgments! Why aren't you even trying to find out the character of a person? Mind, virtue, they lie deep and come out when you need them. Hagen, bring him back! He at least looks good!

Kriemhild: Mom, that's enough for me. I have no desire to find out what lies deep inside this person. Hagen, tell him that he is an interesting individual in very beautiful velvet. I just don't want to have anything to do with him.

Gernot (grabs one of the suitors from the crowd): Sister, look at this one, he is all in diamonds and velvet! Do you know what is sewn on his chest? And he is from the old Behlaren nobility!

Kriemhild: I do not want him, I do not! Hagen, to the rescue!

Hagen: Frankly, Gernot, I would not choose this one in her place either" (Rinke, 2007, pp. 17-18) ${ }^{1}$

This many times repeated description of velvet-clad suitors makes them look preposterous in the eyes of the viewers/readers and more intelligent characters like Kriemhild and Hagen. Clothes cover up the emptiness of the inner world, which is empathized, albeit too straightforwardly, in the same episode:

"Kriemhild: Gentlemen, you look like ice pillars! Sorry, but do I really have to spend my whole life like this? Why do I need these blocks of ice ....Oh, my God, this velvet is everywhere ... Gentlemen, you are so impressively dressed. But I would like you to have at least two thoughts in your head!” (p. 19)

Further the author continues to use the image of clothes as a token of pettiness. This time it is the clothes that the royal family wear that come under the fire. When Siegfried comes to Worms he starts throwing insults around. The quiet yet amazed dignity with which Burgundians meet him leaves Siegfried not much space for mockery, so in order to provoke a fight he pounces at their clothes:

"Siegfried: Are we going to get anywhere further? (He points his sword at Ortwin) Why is there a female hat on this donkey?

Ortwin: I will kill him! (Rushes)

Hagen: (intercepts him) This is my nephew, noble Siegfried. Everyone wears such hats in Burgundy. (to Ortwin) Freeze down!

Ortvin (viciously) It's a Roman hat, Dutchman!

Siegfried: So what? Are we going to discuss hats now?” (p. 25)

1 Translation from German is mine, E. Sarakaeva 
In the next remark Siegfried makes laugh at another character's trousers:

“Siegfried: Am I talking to you, Short Panties?”(p. 25)

Thus, the visual presentation of the epic's characters in the last three centuries made a long way from exaggeratedly "Germanic" idealized bodies to de-idealization, even diminishment in the modern adaptations. The nibelungs, especially Siegfried, the epitome of a Germanic hero, were imagined strong, tall and blond-haired and were admired for that; they are still seen as strong, tall and blond-haired and are ridiculed for that.

But these are adaptations, and they do speak much about about their creators' and their recipients' cultural code. But what about the original poem? Just how blond and tall was Siegfried? Did Hagen have only one eye? Was Brunhild black-haired and Krimhild fair? How did the anonymous author of the great poem actually see the physics of his characters, what did he find important and what did he leave out?

I find it reasonable to first examine the context in which the epic functioned, to see what was typical for the literary works of his time and what was not, what was the tribute to the genre and what must be the author's own invention.

Early medieval works of fiction scarcely describe the appearances of their characters. The Elder Edda, for instance,does not mention the colour of heroines' skin or hair. To a beautiful woman only the adjective "bright" is applied. Thus, Gudrun is 'bjarthaddat man,/dōttur sīna' ("the brighthaired maiden, [Grimhild's] daughter") and has 'bjortum lōfa' ("hand so bright”) (Bellows, 2011: Gripisspa, 33; Guðrunarkviða III, 8).

More detailed description of a character's appearance can be found in Heldenbuch (Hero Book) - the same collection of Medieval verses that contains one of the chief manuscripts of the Nibelungenlied. In the poem about King Ottnit's bridal quest we find the following description of a heroine's appearance (English translation is done by Thomas Carlyle, a remarkable British poet):

"Ihr herz brann also schone

Recht als ein rot rubein

Gleich dem vollen mone

Gaben ihr äuglein schein

Sich hett die maget reine

Mit Rosen wohl bekleid 
Und auch mit berlin kleine.....

......Ihr farb und die war reine,

Liebliech we milch und blut.

Her durch jr zöpffe reinen

Shein jr hals als der schnee”. (Heinzle, 1987, p. 109).

"Her heart burnt with anxiety as beautiful

Just as a red ruby

Like the full moon

Her pretty eyes gave sheen.

Herself had the maiden pure

Well adorned with roses

And also with small pearls....

Her colour it was pure

Lovely as milk and blood.

Out through her pure locks

Shone her neck like the snow.

Her hair was beautifully girt

With noble fine silk,

She let it flow down,

The lovely maidling.

She wore a crown with jewels

It was of gold so red" (Carlyle, 1882, pp. 20-23).

But this kind of description is more of an exception that the rule. Numerous Medieval romances, chronicles and tales of fiction though mention that their heroes and heroines are very beautiful, almost don't describe this beauty, just tell that one character's beautiful appearance makes the other character (and many other people around) fall in love. Thus, we won't find out how exactly the characters of such famous poems as Wolfram von Eschenbach's "Parzival", Chrétien de Troyes's "Erec" or "Yvain", Konrad von Würzburg's "Partonopier" or anonymous poet's "Sir Gowthar" looked like.

Gradually people's faces and figures are granted more and more attention on pages of medieval European chronicles and works of fiction. While George of Tours in his famous "History of Franks" gives scarcely any description of appearance, the longest being about a concubine of one of the Caroling princes who "....had her long and beautiful hair cut off and fixed to a stake" (Gregory of Tours, 1995, p. 46), Einhard begins his "Life of Charlemagne" with a more detailed description of the King's face and figure: 
"Charlemagne was strong and tough in body, and also tall. His head was rounded at the top and his eyes were large and he had white hair, which suited him. His face was open and good-natured. His neck was rather short and thick, and he had something of a pot-belly, but the rest of his body balanced out these features. His movements were all firm and manly. His voice was loud...He enjoyed good health" (Einhard, 1995, p. 49).

This passage is followed by the most minute description of the king's clothes and shoes that he usually wore on different occasions.

This description reminds very much of the impressions that Italian traveler Marco Polo had of Khubilay, the grandson of Genghis Khan:

"He looks like this: of good height, not too short and not too long, of medium height; moderately fat and well built; his face is white and blushing like a rose; his eyes are black, nice, and his nose is as good as it should be" (Wolfe, 2014, p. 411).

These descriptions of ruling males create images of bodily strength (though of a usual human, not super-human heroic type) and aptness for power.

The heroine of Marie de France's "Lanval", a fairy from the Otherworld, lures a knight with her beautiful feminine body and sets him a challenge to test his feelings. In the end the hero is rewarded with lavish gifts and "with physical possession of the idealized, beautiful body" (Saunders, 2007, p. 41). The fairy enchantress is described in the following terms:

"Mut ot le cors bien fait e gent;

Un cher mantel de blanc hermine,

Covert de purpre alexandrine,

Ot pur le chaut sur li geté;

Tut ot descovert le costé,

Le vis, le col e la peitrine;

Plus ert blanche que flur d'espine" (Marie de France, 1978, p. 100).

(Her body was well formed and handsome, and in order to protect herself from the heat of the sun, she had cast about her a costly mantle of white ermine covered withAlexandrian purple. Her side, though, was 


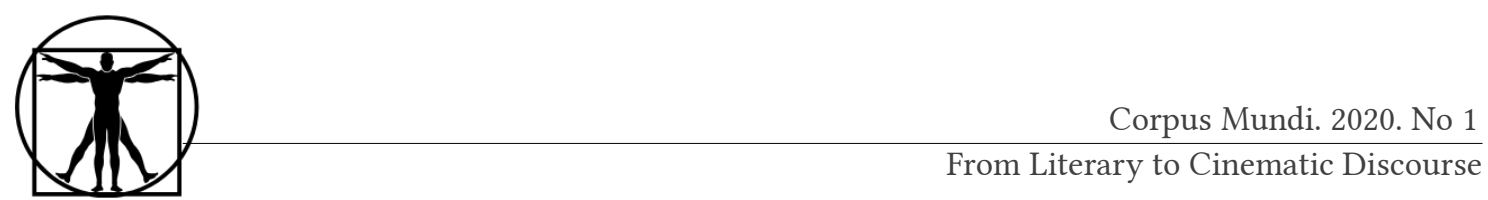

uncovered, as well as her face, neck and breast; she was whiter than the hawthorn blossom) (Burgess \& Busby, 1986, p. 74).

The anonymous Middle English poem "The Wedding of Sir Gawain and Dame Ragnell" is an interesting case. The author mentions the heroine's beauty with a banal phrase "the fairest creature alive" but seems to be mesmerized by ugliness. An ugly person is described with colourful imagery:

"Her face was red, her nose snotid withalle,

Her mouithe wide, her teetheyallow overe alle,

Withe blerid eyengretter then a balle;

Her mouthewas not to lak;

Her teethe hing overe her lippes;

Her cheekis side as wemens hippes;

A luteshe bare upon her back.

Her neck long and therto great;

Her here cloteridon an hepe;

In the sholders she was a yard brode;

Hanging pappis to be an hors lode;

And like a barelle she was made” (Sands, 1966, pp. 231-45).

And a few stanzas below, as if the author can't have enough of this ugliness, he describes the character once more. Here, too, horrible hair, disfigured body and awful monster-like face are lovingly depicted.

A century later European Medieval literature would offer quite elaborate descriptions of appearance. More than 100 (sic!) lines of Wernher de Gartenaere's moralistic poem "Helmbrecht" deal with the character's appearance. The author describes his head, his hair, but especially the clothes and cap that he wore. Then the plot moves to Helmbrecht's dialogue with his father only to return to appearance again. Refusing to engage in farmer's work the title character gives his good looks as the sole reason:

"I'll tell you father, it would not be fair

On my long, flowing, fine and golden hair,

And on my curls and my complexion too,

And on my clothes, so fitting and so new,

And on my cape, the garment that I love,

Embroidered all around with silken doves

Sewn on it by the ladies. Father, no,

Out to the fields I will no longer go!" (Wernher, 1995, p. 93) 
These were the leading trends of character description in the West European literature of XI-XIV centuries: from simple assertion that someone is fair, beautiful and wonderful to mentioning the white skin and rich adornments of ladies and masculine powerful looks of rulers and finally paying more and more attention to fashion and figures.

Against this background we can finally turn to the text of the heroic epic "Das Nibelungenlied" and see what happens there - how the characters are represented and described, what is mentioned and what is omitted.

One of the most minute and full-length descriptions of characters' appearance can be found in the 6thÂventiure when Burgundians led by Siegfried come to Iceland in search for queen Brunhild's hand:

"Rehte in einer mâße den helden vil gemeit von snêblanker varwe ir ros und ouch ir kleit wâren vil gelîche, ir schilde wol getân: die lûhten von den handen den vil wætlîchen man. Ir setele wol gesteinet, ir vürbüege smal: si riten hêrlîche vür Prünhilde sal; dar an sô hiengen schellen von liehtem golde rôt. si kômen zuo dem lande, als eß ir ellen in gebôt, Mit spern niuwe sliffen, mit swerten wol getân, diu $\hat{u} f$ die sporen giengen den wætlîchen man. diu vuorten die vil küenen scharph unde breit. daß sach alleß Prünhilt, diu vil hêrlîche meit. Mit in kom dô Dancwart und ouch Hagene: wir horen sagen mære, wie die degene von rabenswarzer varwe truogen rîchiu kleit. ir schilde wâren niuwe, michel, guot unde breit. Von Indîa dem lande sach man si steine tragen, die kôs man an ir wæte vil hêrlîchen wagen." (Der Nibelunge liet, 1892, p. 134)

(The steeds and garments, too, of the lusty knights, of snow-white hue, were right well matched and all alike; the bucklers, fashioned well, gleamed in the hands of the stately men. In lordly wise they rode to Brunhild's hall, their saddles set with precious stones, with narrow martingales, from which hung bells of bright and ruddy gold. So they came to the land, as well befit their prowess, with newly sharpened spears, with well-wrought swords, the which hung down to the spurs of these stately men. The swords the bold men bore were sharp and broad. 


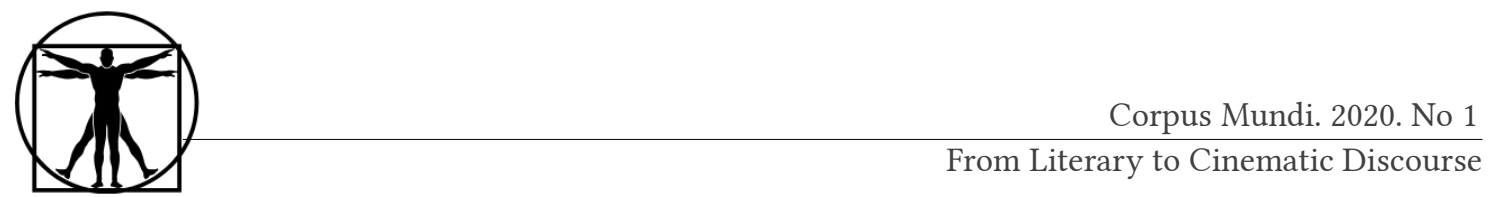

All this Brunhild, the high-born maid, espied. With the king came Dankwart and Hagen, too. We have heard tales told of how the knights wore costly raiment, raven black of hue. Fair were their bucklers, mickle, good and broad. Jewels they wore from the land of India, the which gleamed gloriously upon their weeds) (Schumway, 2002, pp. 72-73).

An attentive reader can single out in this extract a few features very typical for the Lied's narrative:

1. The body parts are not actually described in the extract: neither height nor figures nor complexion nor colour of hair and eyes. Instead the author depicts the characters with general lofty words like "stately men", "high-born maid", "in lordly wise" etc.;

2. Of all the things that the characters have on or carry with them weapons get most space, then come precious stones;

3. The characters are described as seen by somebody else - in this episode the viewers are queen Brunhild and her maids;

4. Of the heroes' clothes we learn that the two with the highest ranks - King Gunther and Prince Siegfried - were clad in white garments embroidered with jewels, the lower ranking men - Hagen and Dankwart - were also dressed magnificently, in black clothes embroidered with pearls. The parallel of their attire will later be the sauce of misunderstanding, when the viewers will fail to recognize the actual feudal relations between the newcomers.

5. The description of characters' apperance is given not when they are introduced for the first time, like in the majority of literary works, but in the middle of the action, right before the important twist of the plot - the subduing of Brunhild and her misinterpretation of Siegfried's role in the situation.

One more description of apperance - and I must say the author of the Lied describes his characters very seldom - occurs in the same Âventiure. When queen Brunhild asks her dames about the newcomers, one of them replies by characterizing each of them one by one. The first two, who are deemed to be the kings, are again described with general lofty words about how lordly they are. Then the lady proceeds by describing the brothers from Tronje:

"Der drite der gesellen der ist sô gremlîch und doch mit schœenem lîbe, küneginne rîch, von swinden sînen blicken, der er sô vil getuot. er ist in sinen sinnen ich wæne grimme gemuot. Der jungeste dar under der ist sô lobelîch: magtlîcher zühte sihe ich den degen rîch 
mit guotem gelæße sô minneclîche stân. wir möhten $\beta$ alle vürhten, hete im hie iemen iht getân.

Swie blîde er phlege der zühte und swie schœne sî sîn lîp, er möhte wol erweinen vil wætlîchiu wîp, swenne er begonde zürnen. sîn lîp ist sô gestalt, er ist in allen tugenden ein degen küene unde balt" (Der Nibelunge liet, 1892, p. 135)

(The third of the fellowship is so fierce and yet withal so fair of body, most noble queen. By the fierce glances he so oft doth cast, I ween he be grim of thought and mood. The youngest among them is worshipful indeed. I see the noble knight stand so charmingly, with courtly bearing, in almost maiden modesty. We might all have cause for fear, had any done him aught. However blithely he doth practice chivalry, and howso fair of body he be, yet might he well make many a comely woman weep, should he e'er grow angry) (The Nibelungenlied, 2002, p. 73).

Here to the features listed above we can add a new characteristics: the personages are not only described as seen by someone else (the dames of Iceland) but also from the viewer's perspective. The female viewers notice that both brothers have beautiful bodies, they find the youngest man charming and worshipful, they compare him to a beautiful girl - yet are aware that both brothers can be potentially dangerous and bring harm to women by killing their husbands and beloved. The description is again placed neither when these characters, Hagen and Dankwart, are first mentioned (that would be the very first Âventiure) nor when they come onto front stage to act or speak (that happens in the third Âventiure), but somewhere midst the adventures, in the situation where violent clash is about to begin.

The only description of appearance that gives an idea about the actual physical appearance of a character happens closer to the end of the poem, in the episode where Burgundians led by Hagen arrive to King Etzel's capital. The king's subjects, the Hunns, run out to look at the guests and are especially interested to see Hagen who has killed the famous dragon slayer Siegfried. What they see is:

"Der helt was wol gewahsen, daß ist alwâr, grôß was er zen brüsten, gemischet was sîn hâr mit einer grîsen varwe, diu bein wârn im lanc, eislîch sîn gesiune, er hete hêrlîchen ganc” (Der Nibelunge liet, 1892, p. 571). 


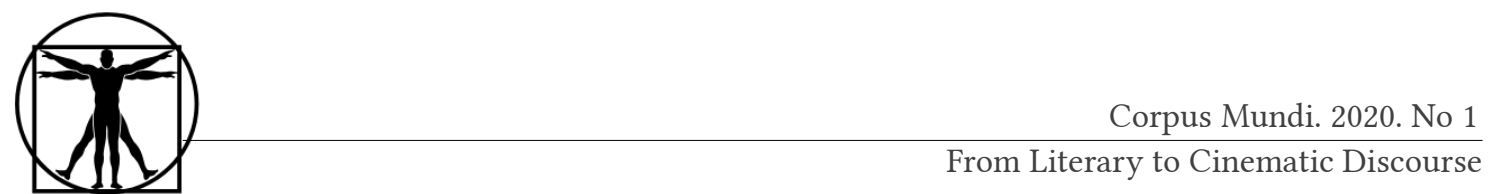

(The knight was fair of stature, that is full true; broad he was across the breast; his hair was mixed with gray; his legs were long, and fierce his glance; lordly gait he had) (Schumway, 2002, p. 200).

Here we can catch the one and only glimpse of actual physical appearance: the hero has broad breast, long legs and greyish hair. But again, the most important thing we learn here is that he was handsome and dangerous, and again the perspective of the viewers determines what exactly is described. Hagen is seen as a powerful warrior whose well built body and menacing looks convey danger, this time to males, who might want to challenge him.

But why him? Why then and there? Why Hagen's apperance is suddenly in the focus of attention at the end of the poem, just before all hell will run loose?

The answer, I believe, is simple - exactly because all hell will run loose!I suggest that the description of the characters' appearance in "Nibelungenlied" performs a special function: it anticipates the conflict, marks the transition to confrontation, signals the beginning of active actions. To prove it, we can analyze the episodes when these descriptions of characters' appearance occur in the poem.

The author does not describe Siegfried's appearance at the very beginning of the story when his biography is set out and he is only planing to come to Burgundy to win the hand of the princess. We learn that he is dreaming of love and that the ladies of the court are very willing to grant him that, but we don't actually see him. We see Siegfried through the eyes of the Burgundians when he has already arrived in Worms and begins to threaten them and to provoke a fight. Together with the Burgundians we evaluate his destructive potential and together with them make a decision not to get involved in a fight with this superdangerous person.

We see four heroes from the Rhine (Siegfried, Hunter, Hagen and Dunkwart) through the eyes of Icelandic women at the moment when these men land on the shores of Iceland to conquer our queen. We pay tribute to their masculine beauty and rich garments; we cannot understand who they are to each other and which of them is the leader, but we try to assess the degree of danger they pose. Together with the Icelandic queen we decide to accept their challenge, but do not expect an easy victory.

We see Hagen through the eyes of the Huns at the moment when he comes fully armed to their capital, ready, without waiting for our attack, to provoke a fight himself in order to play and die by his own rules. No longer hoping for survival, he is willing to shed rivers of blood and to 
drag as many enemies as possible to the next world with him. And so we see him terrible and beautiful at the same time. We look at him from the side, appreciate how dangerous he is and make a decision to avoid skirmishes with him as long as possible (this will happen literally in the next Âventiure, when a whole detachment of armed Huns does not dare to attack Hagen despite queen Krimhild's generous promises).

Thus, the description of the appearance in the "Nibelungenlied" serves not to answer the question "what was this person like" but to indicate what they are going to do. The description of the appearance here is a kind of reconnaissance in battle. It is not for nothing that there is almost no description of females' appearance, and where it occurs - for example, at the scene of the first meeting of Brunhild and Kriemhild - it is also a sort of reconnaissance in battle: the scene contains the allusion to their future quarrel, which would later entail the demise of two states. Appearance in the epic is not a mirror of the soul, as in a later literary tradition. Appearance speaks of readiness for action, is a signal flag for the viewer warning how much and against whom the character is ready to turn his weapon. This function of the appearance description is inherent, it seems to me, only to the "Nibelungenlied", it is a unique, peculiar distinguishing feature of the poem, a special handwriting of its ingenious author.

(To be continued)

\section{References}

Bellows, H. A. (trans.) (2011). Old Norse-English Diglot of the Poetic Edda. Melbourne: Hugo Gering and Karl Hildebrand, ed.

Brecht, B. (1993). Siegfried hatte ein rotes Haar. Aus Große kommentierte Berliner und Frankfurter Ausgabe. Gedichte und Gedichtfragmente 1913-1927. Gedichte 3. Berlin und Weimar / Frankfurt am Main, S. 255f., S. 492.

Burgess, G. S. \& Busby, K., (trans) (1986). of Marie de France. Harmondsworth.

Carlyle, Th. (1882). The Nibelungen lied. NY: The Knickerbocker Press.

Der Nibelunge liet (1892). hrsg. von Karl Simrock. Stuttgart: Verlag der J.G. Gotta'schen Buchhandlung.

Ehrismann, O. (2002). Reception of the Nibelungenlied in Germany. In The Nibelungen Tradition. An Encyclopedia (pp. 219-224). London: Routledge.

Einhard (1995). Life of Charlemagne. In The Deadalus Book of Medieval Literature. The Grin of the Gargoyle (p. 49-50). Sawtry: Dedalus Ltd.

Geibel, E. (1879). Brunhild. A Tragedy from the Nibelung Saga. Boston: Gin and Heath. 


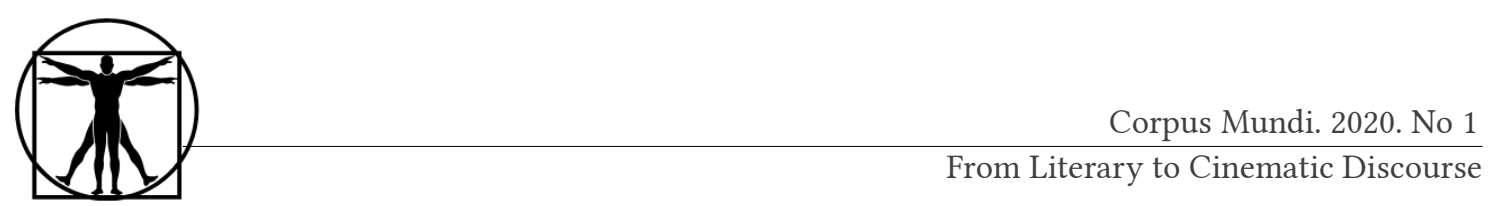

Geibel, E. (1915). Brunhild. Eine Tragödie aus der Nibelungensage. Aus Emanuel Geibels Werke. Fier Teile in einem Bande (pp. 469-562). Leipzig: Hesse und Becker Verlag..

Gregory of Tours (1995). History of Franks. In The Deadalus Book of Medieval Literature. The Grin of the Gargoyle (pp. 43-47). Sawtry: Dedalus Ltd..

Hebbel, F. (1914). Siegfried's Death. In The German Classics of The Nineteenth and Twentieth Centuries, Vol. IX. London: Goodman, Subramanian and PG Distributed. Pp. 169-400

Heinzle, J. (1987). Heldenbuch: nach dem ältesten Druck in Abbildung herausgegeben. Göppingen: Kümmerle.

Herzog, R. (1912). Die Nibelungen. Berlin: Ullstein.

Köstenbaum, W. (1993). The Queen's Throat: Opera, Homosexuality and the Mystery of Desire. New York: Vintage.

Marie de France (1978). Lanval. In A. Ewert (ed.) Lais, Blackwell's French Texts (pp. 5874). Oxford.

Münchhausen, B. von (1959) Das Balladenbuch. Aus Das dichterische Werk in Zwei Bänden. Bd.1.Stuttgart.

Pursell, T. (2008). Queer Eyes and Wagnerian Guys: Homoeroticism in the Art of the Third Reich. Journal of the History of Sexuality, 17(1), 110-137.

Rideamus (1989). Die lustigen Nibelungen. Burleske Operette in drei Akten. Berlin: Felix Bloch Erben.

Rinke, M. (2007). Die Nibelungen. Siegfrieds Frauen / Die letzten Tage von Burgund. Hamburg: Rowohlt Taschenbuch.

Sands, D. (ed.) (1966). The Wedding of Sir Gawain and Dame Ragnell. In Middle English Verse Romances. NY: Holt, Rinehart and Winston.

Sarakaeva, E. A. \& Lebedeva, I. V. (2019). Song of the Nibelungs" as Interpreted by Creative and Political Elites in Germany. In Elitology Issues: Philosophy, Culture, Politics (pp. 149-155). Astrakhan. (in Russian)

Saunders, C. (2007). Erotic Magic: the Enchantress in Middle English Romance. In The Erotic in the Literature of Medieval Britain (pp. 38-52). Cambridge: D.S.Brewer.

Schumway, D. B. (trans) (2002). The Nibelungenlied. Hazleton: Pennsylvania State University Press.

Wagner, R. (1983). Eine Mitteilung an meine Freunde. Aus Dichtungen und Schriften. Hersg von Dieter Borchmeyer. Frankfurt: Insel.

Weinheber, J. (1972). Siegfried-Hagen. Aus Sämtliche Werke. Die Hauptwerke. Salzburg, 1954. S. 311f.

Wernher, de G. (1995) Helmbrecht. In The Deadalus Book of Medieval Literature. The Grin of the Gargoyle (pp. 86-138). Sawtry: Dedalus Ltd.

Wolfe, A. (2014). Marco Polo: Factotum, Auditor. Language and Political Culture in the Mongol World Empire. Literature Compass, 11(7), 409-422 
Yakushenkov, S. N. \& Yakushenkova, O. S. (2010). The Other's Body Through the Prism of a Meeting of Civilizations or Gyulchatay's Face. The Caspian Region: Politics, Economics, Culture, 25(4), 111-117. (in Russian)

\section{Список литературы}

Bellows, H. A. (trans.) (2011). Old Norse-English Diglot of the Poetic Edda. Melbourne: Hugo Gering and Karl Hildebrand, ed.

Brecht, B. (1993). Siegfried hatte ein rotes Haar. Aus Große kommentierte Berliner und Frankfurter Ausgabe. Gedichte und Gedichtfragmente 1913-1927. Gedichte 3. Berlin und Weimar / Frankfurt am Main, S. 255f., S. 492.

Burgess, G. S. \& Busby, K., (trans) (1986). The Lais of Marie de France. Harmondsworth.

Carlyle, Th. (1882). The Nibelungen lied. NY: The Knickerbocker Press.

Der Nibelunge liet (1892). hrsg. von Karl Simrock. Stuttgart: Verlag der J.G. Gotta'schen Buchhandlung.

Ehrismann, O. (2002). Reception of the Nibelungenlied in Germany. In The Nibelungen Tradition. An Encyclopedia (pp. 219-224). London: Routledge.

Einhard (1995). Life of Charlemagne. In The Deadalus Book of Medieval Literature. The Grin of the Gargoyle (p. 49-50). Sawtry: Dedalus Ltd.

Geibel, E. (1879). Brunhild. A Tragedy from the Nibelung Saga. Boston: Gin and Heath.

Geibel, E. (1915). Brunhild. Eine Tragödie aus der Nibelungensage. Aus Emanuel Geibels Werke. Fier Teile in einem Bande (pp. 469-562). Leipzig: Hesse und Becker Verlag..

Gregory of Tours (1995). History of Franks. In The Deadalus Book of Medieval Literature. The Grin of the Gargoyle (pp. 43-47). Sawtry: Dedalus Ltd..

Hebbel, F. (1914). Siegfried's Death. In The German Classics of The Nineteenth and Twentieth Centuries, Vol. IX. London: Goodman, Subramanian and PG Distributed. Pp. 169-400

Heinzle, J. (1987). Heldenbuch: nach dem ältesten Druck in Abbildung herausgegeben. Göppingen: Kümmerle.

Herzog, R. (1912). Die Nibelungen. Berlin: Ullstein.

Köstenbaum, W. (1993). The Queen's Throat: Opera, Homosexuality and the Mystery of Desire. New York: Vintage.

Marie de France (1978). Lanval. In A. Ewert (ed.) Lais, Blackwell's French Texts (pp. 5874). Oxford.

Münchhausen, B. von (1959) Das Balladenbuch. Aus Das dichterische Werk in Zwei Bänden. Bd.1.Stuttgart.

Pursell, T. (2008). Queer Eyes and Wagnerian Guys: Homoeroticism in the Art of the Third Reich. Fournal of the History of Sexuality, 17(1), 110-137. 


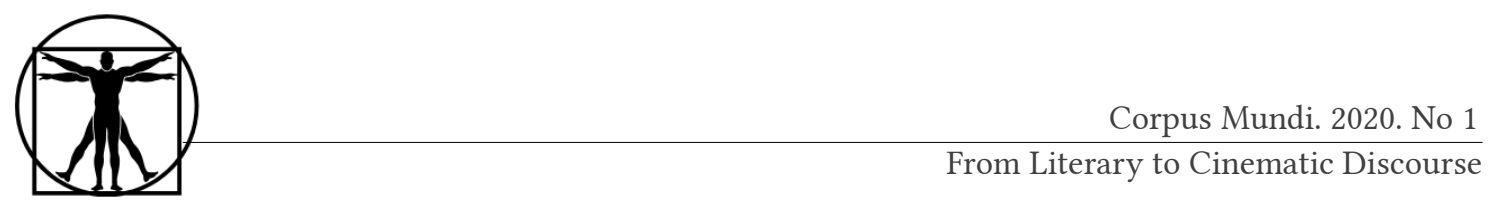

Rideamus (1989). Die lustigen Nibelungen. Burleske Operette in drei Akten. Berlin: Felix Bloch Erben.

Rinke, M. (2007). Die Nibelungen. Siegfrieds Frauen / Die letzten Tage von Burgund. Hamburg: Rowohlt Taschenbuch.

Sands, D. (ed.) (1966). The Wedding of Sir Gawain and Dame Ragnell. In Middle English Verse Romances. NY: Holt, Rinehart and Winston.

Saunders, C. (2007). Erotic Magic: the Enchantress in Middle English Romance. In The Erotic in the Literature of Medieval Britain (pp. 38-52). Cambridge: D.S.Brewer.

Schumway, D. B. (trans) (2002). The Nibelungenlied. Hazleton: Pennsylvania State University Press.

Wagner, R. (1983). Eine Mitteilung an meine Freunde. Aus Dichtungen und Schriften. Hersg von Dieter Borchmeyer. Frankfurt: Insel.

Weinheber, J. (1972). Siegfried-Hagen. Aus Sämtliche Werke. Die Hauptwerke. Salzburg, 1954. S. 311f.

Wernher, de G. (1995) Helmbrecht. In The Deadalus Book of Medieval Literature. The Grin of the Gargoyle (pp. 86-138). Sawtry: Dedalus Ltd.

Wolfe, A. (2014). Marco Polo: Factotum, Auditor. Language and Political Culture in the Mongol World Empire. Literature Compass, 11(7), 409-422

Саракаева, Э. А. \& Лебедева, И. В. (2019). “Песнь о нибелунгах” в интерпретации творческих и политических элит Германии. В Вопросы элитологии: философия, культура, политика (стр. 149-155). Астрахань.

Якушенков, С. Н. \& Якушенкова, О. С. (2010). Чужое тело сквозь призму встречи цивилизаций, или личико Гюльчатай. Каспийский регион: политика, экономика, культура, 25(4), 111-117. 